\title{
Food Security Towards Sustainable Development of Food Security in Indonesian Provinces
}

\author{
Jakaria*, Lydia Rosintan Simanjutan \\ Faculty of Economics and Business \\ Universitas Trisakti \\ Jakarta, Indonesia \\ *jakaria.fe@trisakti.ac.id
}

\begin{abstract}
Food security is essential in order to fulfil other fundamental human rights, such as education, health, and employment. Its sufficiency is essential for availability, accessibility, stability, and utilization. This research, therefore, aims to examine the problems associated with food security among provinces in Indonesia. The purposive sampling method was used to obtain data on the availability, accessibility, and stability of food from 33 provinces from 2012-2016. In addition, the analytical method was used to determine the index of food security in accordance with the distance to scale. The research showed that the provinces with the best food security were Bali and South Kalimantan, while Jambi, East Nusa Tenggara, North Maluku, Maluku, West Papua, and Papua had a very low index. In conclusion, availability and accessibility are the main factors that weaken food security in every province in Indonesia.
\end{abstract}

Keywords-food security, availability, accessibility, stability, distance to scale

\section{INTRODUCTION}

Food security is a major multidimensional issue that covers economic, social, political, and environmental aspects of society. FAO [1] stated that its dimensions consist of 4 aspects, namely: (1) Availability, (2) Access to good and nutritious food, (3) Stability to always obtain good food that are free from shocks such as the economic and climate crisis and (4) Utilization, in accordance with adequate knowledge of health and sanitation issues associated with its consumption.

Food is the main basic need for humans, therefore, it is the right for every individual to obtain an adequate amount daily [2]. By definition, food is any biological, animal, and water source that is processed and consumed by humans. In 2016, the Economics Intelligence Unit (EIU) stated that based on the food security index, most countries in Africa are faced with food problems with the majority at quartile 1 , which is in the range of index numbers between $24 \%$ to $41.50 \%$. Countries in the Asian are generally at quartiles 2 and 3 with index scores ranging from $41.6 \%$ to $57 \%$ and $57.1 \%$ to $72.3 \%$, respectively. Meanwhile, developed countries, such as Australia, Japan, South Korea, the United States, countries in Europe, Canada, and some South American nations, have a high level of food security with index scores ranging from $72.4 \%$ to $86.6 \%$.

The problem associated with food security is not only based on the availability of lands and production. However, it also relates to other aspects, such as accessibility, stability, and utilization. This is one of the reasons why Indonesia's position for food security is among the lowest compared to Singapore, Malaysia, Thailand, and Vietnam, despite having the most significant agricultural landmass in Southeast Asia. In 2016, Indonesia's food security ranking was only higher than the Philippines, with an index score of $50.6 \%$ in the $72^{\text {nd }}$ position. The Philippines had a food security index score of $49.5 \%$ and ranked $74^{\text {th }}$. In 2016, Singapore ranked $3^{\text {rd }}$ in the world with a high food security index of $83.9 \%$ among ASEAN countries, followed by Malaysia at $35^{\text {th }}$ with $69 \%$, Thailand at $51^{\text {st }}$ with $59.5 \%$, and Vietnam at $57^{\text {th }}$ with $57.1 \%$.

In accordance with the trade-off, Indonesian food resources are unusually large, however, its security ranks far lower than some ASEAN countries such as Singapore, Malaysia, and Thailand. This research was, therefore, conducted to map food security among provinces in Indonesia from 2012-2016.

\section{LITERATURE REVIEW}

\section{A. Food Security}

Braun et al stated that the use of the term food security is widely debated and multi-interpreted due to its broadness [3]. Braun further stated that this definition tends to change due to the breadth of food security in accordance with the purpose and availability of the existing data.

Ballenger and Mabbs-Zeno divided food security into three types [4], namely (1) Global Food Security which requires its availability in sufficient amount to fulfil the needs of the community, (2) National Food Security which is its available for consumption in a country throughout the year, (3) Individual Food Security which is the income from each person that is enough to fulfil all their needs.

Food Security Indicators by FAO was measured using 4 pillars (dimensions), as follows. First, Availability: the 
accessibility of safe, equitable, and affordable food in quantity and quality, for households. Second, Access: the physical, economic, and social access or affordability of food in a locality. Third, Stability: this is the ability of the community to access and use food with stable and sustainable conditions over time. Fourth, Utilization: the community has basic knowledge and sanitation conditions for selecting, preparing, and distributing food through a method that produces good nutrition.

\section{B. Methods}

This is a quantitative research used to provide a comprehensive explanation of food security among provinces in Indonesia. Data were obtained by calculating the food security index consisting of 3 dimensions, namely availability, accessibility, and stability, with the utilization used due to limited data in each province.

The data utilized in this research were secondarily obtained by conducting library research from various agencies, namely the Central Bureau of Statistics (BPS) [5-9], United National Development Project (UNDP) [10-13], Bank of Indonesia, and Ministry of Agriculture. Most of the research data were obtained from reports of Central Bureau of Statistics, Indonesian Statistics, National Socio-Economic Survey (Susenas), Indonesian Human Development Index (HDI), Gross Regional Domestic Product (GRDP), Projection of Indonesian Population by Province, as well as People's Welfare and Socio-Economic Statistics.

This research was conducted in 33 provinces from 20122016. However, the North Kalimantan province was not included because it was newly created, and the availability of its data started in 2013.

The food security variables measured using 3 dimensions were used to carry out this research as follows:

1) Availability: Measurement for this dimension uses 5 indicators, such as average food energy adequacy (calories/ capital), the average value of food production (production/capita), percentage of energy supply from cereals, roots, and tubers (calories/capita), average protein supply (gr/cap/day), and the average supply of protein derived from animals (gr/cap / day).

2) Access: Measurement for Gross Domestic Product per capita that reflects the purchasing power Food Price Index $(\%)$, The prevalence of malnutrition $(\%)$ as measured by the average calorie consumption /capita in each province to the national level, percentage of expenditure on food for each province (\%), and the level of food deficit is the difference between the average and consumed energy in each province.

3) Stability: Measurement for domestic food fluctuation is the standard deviation of its inflation during this research, variability of food production per capita as measured by its standard deviation per capita during the research period in each province, the volatility of food supply per capita as measured by the standard deviation of food consumption per calorie/capita/day.

All research data were obtained from reports of the Central Bureau of Statistics including Indonesian Statistics, National Socio-Economic Survey (Susenas), Indonesian Human Development Index (HDI), Gross Regional Domestic Product (PDRB), Projection of Indonesian Population by Province, as well as People's Welfare, and Socio-Economic Statistics.

\section{METHODS}

The food security index was calculated in the following stages [14]:

- Identify the variables to be used in calculating the food security index and determine whether the relationship is positive or negative. From the measurement indicators made by FAO, only 13 indicators were used in the research.

- By using the distance to scale method, each variable was changed to an index by giving a value of 100 to the province with the best value.

- For indicators with a positive relationship to food security, the province with the highest value has an index value of 100 , while others are below 100 . The formulation to change the index value for each variable with a positive relationship is stated in the following formula:

$$
\text { Indeks } x_{i j}=\frac{\left(x_{i j}-\min (x)\right)}{(\max (x)-\min (x))} \times 100
$$

Where

$\mathrm{X}_{\mathrm{ij}}$ index $=$ index value of certain variables in the $\mathrm{i}$ th province in $\mathrm{j}$-th year

$\mathrm{Xij}=$ value of a certain variable in the $\mathrm{i}$-th province in $\mathrm{j}$-th year

$\max (\mathrm{X}) \quad=$ maximum value for certain variables in a particular province in the $\mathrm{j}$-th year

- For indicators with a negative relationship to food security, the province with the lowest value has an index of 100, while those with a higher value are below 100. The formulation to change the index value for each variable with a negative relationship with food security for each province is stated in the following formula

$$
\begin{aligned}
& \text { Indeks } \mathrm{X}_{\mathrm{ij}}=\frac{\left(\mathrm{x}_{\mathrm{ij}}-\operatorname{man}(\mathrm{X})\right)}{(\min (\mathrm{X})-\max (X))} \times 100 \\
& \text { Where } \quad=\text { index value of certain variables in } \\
& \mathrm{X}_{\mathrm{ij}} \text { Index } \quad=\text { the value of certain variables in } \\
& \text { the i-th province in } \mathrm{j} \text {-th year } \\
& \begin{array}{l}
\mathrm{X} \text { ij } \\
\text { the } \mathrm{i} \text {-th province in } \mathrm{j} \text {-th year }
\end{array}
\end{aligned}
$$




$$
\mathrm{X}_{\operatorname{minj}}
$$

$=$ the minimum value for certain variables in certain provinces in $\mathrm{j}$-th year

- Calculate the food security index for each dimension, namely availability, accessibility, stability, and utilization using the following formula:

Indeks $D_{i j}=\frac{\text { Index } X_{i j}}{n}$

Where:

$\mathrm{D}_{\mathrm{ij}}=$ Food security index of the $\mathrm{i}$-th dimension in $\mathrm{j}$-th year

Indeks $\mathrm{X}_{\mathrm{ij}}=$ Food security index of the $\mathrm{i}$-th indicator in j-th year

$\mathrm{N}=$ Number of food security indicators for certain dimensions

- Calculate the aggregate food security index, which is a composite of the dimensions of availability, accessibility, stability, and utilization. Based on the results of the discussion through FGD (Focus Group Discussion), a weighting scenario to calculate the food security index was formulated as follows:

\section{Availability dimension weights $40 \%$}

2. Access dimension weights $35 \%$

3. Stability dimension weights $25 \%$

Based on the above weights, the formulation for calculating Food Security is stated as follows:

$\mathrm{FSI}_{\mathrm{ij}}=0,4 \mathrm{AVAIL}_{\mathrm{ij}}+0,35 \mathrm{ACCESS}_{\mathrm{ij}}+0,25 \operatorname{STABIL}_{\mathrm{ij}}(2)$

Where:

FSI $_{\text {IJ }}:$ Food Security Index of the i-th province in $\mathrm{j}$-th year

AVAIL $_{\mathrm{ij}}$ : Food security index of availability dimension

ACCESS $_{\mathrm{ij}}$ : Food security index of accessibility dimension of the $\mathrm{i}$-th province in $\mathrm{j}$-th year

STABIL $_{\mathrm{ij}}$ : Food security index of stability dimension of the $\mathrm{i}$-th province in $\mathrm{j}$-th year

\section{RESULTS AND DISCUSSION}

\section{A. Result}

The results of the calculation of the food security index for 33 provinces in Indonesia from 2012-2016 were below 50\%, except in 2015 , where it is $51.61 \%$, as shown in table 1 . During this period, 2 provinces were consistently at a moderate level, and this condition was the same from 2007-2011. The two provinces were Bali and South Kalimantan.

From 2012-2016, 6 provinces had low food security, namely: Jambi, East Nusa Tenggara, North Maluku, Maluku, West Papua, and Papua.

Overall, the low food security faced by the Indonesian provinces was below 50\% from 2012-2016. Based on the mapping of the access dimension, eastern Indonesia had a low access index. However, there was an improvement in the value in 2016 , by less than $50 \%$ compared to the previous year.

The availability dimension provided the second-lowest contribution in the formation of low food security that occurred in provinces from 2012-2016. The development of the availability index value also showed improvement except for provinces in eastern Indonesia.

The food security index showed a fairly good performance during this period, with an average index above $50 \%$. Based on the mapping, only the Jambi province consistently had a stability index at a very low level while others were in a good category, which was above $50 \%$.

Figure 1 shows the mapping of food security among provinces in Indonesia from 2012-2016.

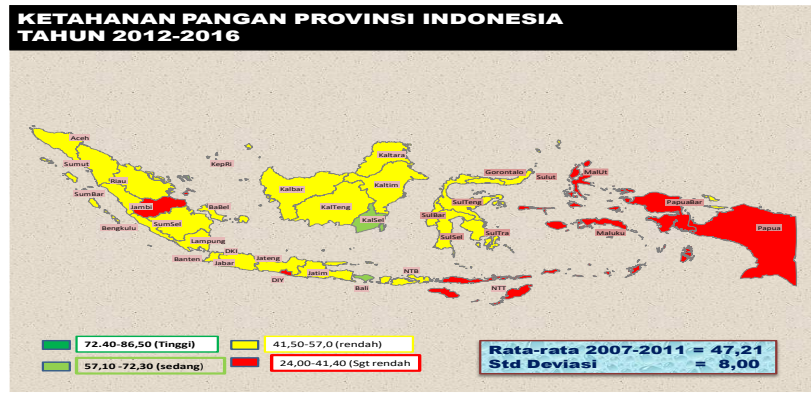

Fig. 1. Map of Food Security among Provinces in Indonesia in 2012-2016.

TABLE I. FOOD SECURITY INDEX AMONG PROVINCES IN INDONESIA IN 2012 - 2016

\begin{tabular}{|l|l|l|l|l|c|}
\hline \multirow{2}{*}{ No } & \multirow{2}{*}{ Province } & \multicolumn{5}{|c|}{ AVERAGE FOOD SECURITY INDEX 2012-2016 } \\
\cline { 3 - 6 } & & $\boldsymbol{A} \boldsymbol{V} \boldsymbol{A} \boldsymbol{I} \boldsymbol{L}$ & $\boldsymbol{A C C E S \boldsymbol { S }}$ & $\boldsymbol{S} \boldsymbol{\text { TABIL }}$ & $\boldsymbol{F S}$ \\
\hline 1 & ACEH & 47.97 & 37.84 & 67.81 & 49.38 \\
\hline 2 & SUMUT & 50.28 & 40.93 & 64.46 & 50.55 \\
\hline 3 & SUMBAR & 55.90 & 46.77 & 62.98 & 54.48 \\
\hline 4 & RIAU & 43.10 & 51.85 & 63.16 & 51.18 \\
\hline 5 & JAMBI & 41.45 & 41.74 & 11.37 & 34.03 \\
\hline 6 & SUMSEL & 56.73 & 47.48 & 69.71 & 56.74 \\
\hline 7 & BENGKULU & 49.32 & 43.00 & 65.77 & 51.22 \\
\hline 8 & LAMPUNG & 45.10 & 35.34 & 68.15 & 47.45 \\
\hline 9 & KEP. BABEL & 44.48 & 43.09 & 50.78 & 45.57 \\
\hline
\end{tabular}


Table 1. Cont.

\begin{tabular}{|c|c|c|c|c|c|}
\hline \multirow{2}{*}{ No } & \multirow{2}{*}{ Province } & \multicolumn{4}{|c|}{ AVERAGE FOOD SECURITY INDEX 2012-2016 } \\
\hline & & $A V A I L$ & ACCESS & STABIL & $F S$ \\
\hline 10 & KEPRI & 50.44 & 57.22 & 59.54 & 55.09 \\
\hline 11 & DKI & 44.79 & 66.54 & 67.63 & 58.12 \\
\hline 12 & JABAR & 46.29 & 43.51 & 78.14 & 53.28 \\
\hline 13 & JATENG & 35.85 & 37.42 & 80.37 & 47.53 \\
\hline 14 & DIY & 47.48 & 50.66 & 66.51 & 53.35 \\
\hline 15 & JATIM & 41.90 & 42.85 & 71.40 & 49.61 \\
\hline 16 & BANTEN & 48.90 & 48.54 & 58.70 & 51.23 \\
\hline 17 & BALI & 66.13 & 68.60 & 64.03 & 66.47 \\
\hline 18 & NTB & 60.81 & 46.76 & 60.40 & 55.79 \\
\hline 19 & NTT & 42.42 & 30.92 & 49.92 & 40.27 \\
\hline 20 & KALBAR & 49.15 & 34.28 & 81.85 & 52.12 \\
\hline 21 & KALTENG & 56.70 & 47.42 & 56.54 & 53.41 \\
\hline 22 & KALSEL & 62.86 & 53.56 & 79.87 & 63.86 \\
\hline 23 & KALTIM & 34.41 & 51.33 & 66.03 & 48.24 \\
\hline 24 & SULUT & 56.06 & 45.65 & 54.80 & 52.10 \\
\hline 25 & SULTENG & 46.35 & 43.30 & 70.28 & 51.27 \\
\hline 26 & SULSEL & 64.55 & 46.64 & 48.68 & 54.31 \\
\hline 27 & SULTRA & 51.36 & 47.14 & 69.47 & 54.41 \\
\hline 28 & GORONTALO & 49.99 & 44.75 & 64.82 & 51.86 \\
\hline 29 & SULBAR & 54.80 & 45.64 & 43.32 & 48.72 \\
\hline 30 & MALUKU & 28.91 & 27.16 & 48.94 & 33.31 \\
\hline 31 & MALUT & 18.62 & 22.45 & 55.61 & 29.21 \\
\hline 32 & PAPBAR & 27.85 & 31.63 & 53.33 & 35.54 \\
\hline 33 & PAPUA & 26.84 & 23.90 & 71.32 & 36.93 \\
\hline \multicolumn{2}{|c|}{ MEANS } & 46.90 & 43.81 & 61.99 & 49.59 \\
\hline \multicolumn{2}{|c|}{ STAD DEVIATION } & 11.02 & 10.26 & 13.22 & 8.32 \\
\hline
\end{tabular}

\section{B. Discussion}

The research findings showed that accessibility was a dimension of food security that provided the biggest contribution to its low index in each province. In addition, the low access dimension was caused by several main factors namely: (1) The Gross Domestic Product per capita from 2012 -2016 which had an average of $18.5 \%$, (2) The average percentage of household expenditure for food with an average index of $37.5 \%$, because the largest portion was dominated by consumption for food with an average of $52.018 \%$, where 26 provinces consumed more than $50 \%$ of food, and 7 consumed less than $50 \%$. (3) The prevalence of malnutrition had an average index of $47.5 \%$, where 19 and 14 provinces had high and low prevalence, respectively.

\section{CONCLUSION}

Based on the research findings, the following conclusions were made: Food security index for each province in Indonesia from 2012-2016 was at a low level, except for Bali and South Kalimantan. The Access Dimension provided the biggest contribution to the low food security index for each province, where Eastern Indonesia dominated. The availability dimension was the second that contributed to the low food security index of each province. The stability dimension provided the best contribution in the formation of food security for each province.

\section{REFERENCES}

[1] FAO, Food Security Indicators, 2017

[2] Undang-Undang Republik Indonesia Nomor 7 Tahun 1996 tentang Pangan

[3] J.V. Braun, K.S. Bouis and R.P. Lorch, Improving Food Security of The poor : Concept, Policy, and Programs. Washington, D.C.: International Food Policy Research Institute, 1992.

[4] N. Ballenger and C. Mabbs-Zeno, "Treating Food Security and Food Aid Issues at the GATT," Food Policy, vol. 17, no. 4, pp. 264-276, 1992.

[5] BPS, 2007 - 2016, Indeks Pembangunan Indonesia.

[6] BPS, 2007 - 2016. Konsumsi Kalori dan Protein Penduduk Indonesia dan Provinsi 2007: Berdasarkan Hasil Susenas Panel.

[7] BPS, 2007 - 2016. Konsumsi Kalori dan Protein Penduduk Indonesia dan Provinsi 2007: Berdasarkan Hasil Susenas Panel

[8] BPS, 2007 -2016. Pengeluaran Untuk Konsumsi Penduduk Indonesia, SUSENAS.

[9] BPS, 2007-2016. Produk Domestik Regional Bruto Provinsi-provinsi di Indonesia Menurut Lapangan Usaha

[10] The Economics Inteelligence Unit, Global Food Security Index, 2006.

[11] UNDP, Human Development Report, 1990.

[12] UNDP, Human Development Report, 1996.

[13] UNDP, Human Development Report, 2016.

[14] S.R. Nurhemi, G.S.R. Soekro and R. Suryani, Pemetaan Ketahanan Pangan di Indonesia: Pendekatan TFP dan Indeks Ketahanan Pangan. Jakarta: Bank Indonesia, 2014. 